\section{Creation research and Noah}

SIR - Jukes's commentary on his caricature of creation (Nature 308, 398-400; 1984) is a superb illustration of the unscientific approach of the anti-creationists, especially his conjuring up of "data" to support his polemic. Contrary to Jukes's demonstrably false claims, I have never sent graduate students to do field research on fossil human footprints (although I have led them on Grand Canyon field studies), have never even considered specializing in the "ecology of Noah's Ark", and certainly did not (indeed, could not) synthesize the Taylor's sophisticated museum display with which I am pictured. In the "half (or one-tenth) truth" category, Jukes labours the fact that I wrote a children's book on fossils, but mentions neither that the book was written for Christian families (not at all for public schools) nor that I have co-authored two two-model books with quite a different approach for public schools and, with a highly respected biologist, four widely used college programmed textbooks in biology. His misrepresentation of my colleagues and other aspects of creation science are even further off the mark.

If Jukes (unfortunately rather typical of the anti-creationists) cannot be trusted accurately to report simple, easily obtainable facts verifiable in the present, how can anyone trust his wild-eyed speculations about the complex and unobservable past? It is sad to see a man of Jukes's former stature sink so low. But if Nature (a refereed journal?) and those evolutionists who are scientists want to retain a claim to fair and objective scientific rationality, they must separate themselves publicly from Jukes's pitiful tantrum. At least Jukes's article will make thinking people everywhere wonder what is wrong with eliminating "the current methods for teaching evolution" 'if he exemplifies them.

\section{Graduate School,}

Institute for Creation Research,

2100 Greenfield Drive,

El Cajon, California 92021, USA

- Jukes replies - Professor Parker incorrectly states that I wrote a caricature of "creation". My article was about creationism, a rather different topic.

Parker says he has "never sent graduate students to do field research on human footprints"'. However, this topic of graduate study is listed in the Institute for Creation Research (ICR) General Catalog (p.14). His "Grand Canyon field studies" would presumably be related to his assertion (Parker, Dry Bones, pp.53-54) that the canyon was formed 5,000 years ago by the Great Flood. Although he "did not ... synthesize the Taylor's sophisticated sic museum display", an essentially similar pictorial representation appears in Dry Bones p. 24.
Parker's speciality on the ecology of Noah's Ark was inferred by me from Dry Bones, which devotes about 16 pages to Noah's Ark and the flood, with pictorial details of the fauna and their food supply.

Parker says I did not mention that Dry Bones was written for Christian families. The book is offered for public sale in the ICR book catalogue, where it is described as "fun as well as educational". Despite Parker's assertions, Dry Bones has been used for science instruction in at least one public school, where it aroused protest by families that include Christians. I did not find it necessary to publicize his other literary efforts.

I made no misrepresentation of his colleagues; I let them speak for themselves. Parker speaks of my "wild-eyed speculations about the complex and unobservable past"'. The best response is to quote some of Parker's own pronouncements. For example:

"If the fossils are the plants and animals drowned in Noah's Flood, then they would all be about five to seven thousand years old." (loc. cit., p. 44).

"Before the Flood there were many more plants without seeds compared to seed plants. Plants without seeds didn't survive the Flood as well seed plants."

\section{University of California,}

THOMASH. JUKES

\section{Berkeley, California 94720, USA}

\section{Semen and AIDS}

SIR - In the letter "Semen and AIDS", by G.M. Shearer and A.S. Rabson (Nature 15 March, p.230), some consequences of the physiology of mammalian reproduction appear to have been overlooked.

It is true that semen is deposited in the vagina which is lined by stratified, squamous epithelium, but to reach the ovum sperms have to ascend through the endocervix which is lined by tall columnar (picket) epithelium. This is less likely to be traumatized than the rectal mucosa of a catamite, but its penetration by sperms has been invoked in explaining the origin of carcinoma, while anti-sperm antibodies are common in the human female.

The Old House,

R.E. REWELL

Vowchurch,

Herefordshire HR2 ORB, UK

\section{Fetal viability}

SIR - Dr Jansen's choice of definition of "previable" is not as plain as he thinks (Nature 26 April, p.768). The de facto legal definition of viability is currently 28 weeks in the United Kingdom. The National Health and Medical Research Council (NH \& MRC) of Australia suggests 20 weeks; others suggest 22 or 24 weeks as the medical definition of viability. If there is " $a$ point at which extrauterine existence is possible", it would appear to extend over an eight-week period, which is a mathematical contradiction. But, of course, there is no "point", not even 20 weeks, because NH \& MRC had to provide a rider to this choice when it stated that "dissection of the fetus should not be carried out while a heartbeat is still apparent or there are other obvious signs of life"'.

Dr Goodhart's choice of definition (Nature 26 April, p.768) appears more reasonable but on analysis is seen to contain a major flaw. The span of human existence from conception until death may be divided into 9 months in a fluid environment and the remainder in an air environment. It is axiomatic to state that the fetus flourishes in its fluid environment, even if it may die in that environment. It is illogical, therefore, to relate the viability of the fetus to its unnatural extrauterine state, just as it would be illogical to relate the viability of those born to their ability to survive in a fluid environment once again.

The best definition of the term "viable" in relation to the embryo or fetus that I could find is "capable of maintaining life". The term "previable" adds nothing to our understanding of intrauterine human existence. PATRICK W. GILL Neath General Hospital, Neath, Glamorgan SA11 2LQ, UK

\section{Biological control}

SIR - May I add to the list of methods suggested for control of the fly in a domestic environment? Curiously, neither F.E.G. Cox $^{1}$ nor K.L. Bell ${ }^{2}$ have considered the possibility of biological control There are several advantages to be gained from establishing a flourishing domestic population of the fly's natural predator, the spider. In particular, application of this means of control would overcome the moral dilemma posed by the choice between swatting the fly and forcibly expelling the insect into an often hostile world.

As in all habitats, it is important to maintain a correct ecological balance within the home or laboratory. Nevertheless, my proposal is preferable to a more drastic form of biological control recorded many years ago. As pointed out by $\mathbf{R}$. Bonne $^{3}$, direct predation of flies by humans (particularly elderly females) would seem to be unwise. It can be the beginning of a surprising food chain which, if this anecdotal account is to be believed, can have serious medical consequences and can even result in death in extreme cases.

MiChAEL J. ClemENS

Department of Biochemistry,

St George's Hospital Medical School,

Canmer Terrace,

London SWI7 ORE, UK

1. Cox, F.E.G. Nature 307, 8 (1984).

2. Bell, K.L. Nature 308, 684 (1984)

3. Bonne, R. There was an Old Lady who Swallowed a Fly (Southern Music Publishing Co. Ltd.). 